\title{
The preparation and course of the land reform in Slovakia, 1939-1945
}

\author{
MARTINA F I A M O V Á
}

FIAMOVÁ, Martina. The preparation and course of the land reform in Slovakia, 1939-1945. Historický časopis, 2018, 66, 5, pp. 901-932, Bratislava.

The subject matter of land reform and the related issue of ensuring that land was owned by ethnic Slovaks, had already appeared in Slovakia in the time of autonomy after 6 October 1938. Reflections about the change of land ownership from the beginning referred not only to Jews, but also to the land of foreigners, the land allotted within the 1st land reform, as well as to the land of Slovaks. The prepared land reform was supposed to compensate for the iniquities caused by the 1 st land reform and return the land back "to the hands of those who truly work on it". Unlike the owners of shops and enterprises, Jewish landowners did not represent a very large class of people, but even in spite of this fact, the following Aryanization of this Jewish land property was subject to corruption. The local and state authorities as well as common people participated in the process of transferring Jewish land into the hands of "Aryans". However the Slovak government failed in its effort to create a strong middle class of peasants who would support Hlinka's Slovak People's Party.

Key words: Land reform. Agricultural policy. Aryanization.

DOI: https://doi.org/10.31577/histcaso.2018.66.5.5

Solution of property relations in the Slovak countryside and its development was one of the basic problems that every regime in the 20th century had to confront. ${ }^{1}$

1 For further details on the problem of the development of land holding in the period 1939-1945 see e.g.: BAUCH, Vlastislav - KONTRA, Martin. Príspevok k otázke postavenia malých rol'níkov za tzv. slovenského štátu. (A contribution to the question of the position of small farmers in the so-called Slovak state). In Ekonomický časopis, 1955, year 3, no. 1, p. 77 96; BAUCH, Vlastislav. Pozemková reforma za tzv. Slovenského štátu. (Land reform in the so-called Slovak state). In Ekonomický časopis, 1956, year 4, no. 4, p. 364-385; BAUCH, Vlastislav. Pol'nohospodárstvo za slovenského štátu. (Agriculture in the Slovak state). Bratislava: Slovenské vydavatel'stvo politickej literatúry, 1958, 181 p.; CAMBEL, Samuel. Sociálno-ekonomické a politické východiská slovenskej pozemkovej reformy (1938 - 1945). (The socio-economic and political starting points of Slovak land reform (1938-1945)). In Historický časopis, 1993, year 41, no. 5-6, p. 654-667. ISSN 0018-2575; CAMBEL, Samuel. Arizácia a d’alšie zmeny v pozemkovej držbe na Slovensku do leta 1944. (Aryanization and other changes in land holding in Slovakia up to 1944). In Historický časopis, 1995, year 43, 
The first substantial attempt to change the existing system of land ownership was the land reform after 1919, but it did not solve either the social or the national questions in Slovakia. It brought some changes in the direction of strengthening middle level farmers, but it could not remove the small-scale domestic character of farming. In 1930, more than $88 \%$ of all agricultural businesses in Slovakia had less than $10 \mathrm{ha}^{2}$ of land and according to the Slovak Minister of Agriculture Gejza Medrický in February 1941, up to 65\% of farming households had no more than 5 ha of land. ${ }^{3}$

According to G. Medrický, 1,407,359 ha of Slovak land were confiscated under the inter-war Czechoslovak land reform. 562,078 ha were left to the original owners, while 684,880 ha went to new owners. ${ }^{4}$ However, according to the historian Jiří Doležal, 1,396,135 ha of Slovak land, 36\% of it agricultural was taken in Slovakia up to 1937. A total of 690,525 ha was distributed to almost 190,000 persons, with 187,423 of these gaining small plots (of up to 30 ha) amounting to a total of 290,543 ha $(247,570$ ha of agricultural land). Among the others, 594 gained 74,654 ha, while 1,437 were awarded 325,327 ha in the form of larger complexes. The historian Vlastislav Bauch states that 186,648 people

no.1, p. 69-89. ISSN 0018-2575; CAMBEL, Samuel. Pol’nohospodárska politika a pozemková reforma na Slovensku v rokoch 1939 - 1944. (Agricultural policy and land reform in Slovakia, 1939-1944). In RAŠTICOVÁ, Blanka (ed.). České a slovenské zemédělství v letech 2. světové války. Studie Slováckého muzea. Uherské Hradiště: Slovácké muzeum, 1996, p. 7-16. ISBN 8090191355; CAMBEL, Samuel. Slovenská dedina (1938 - 1944). (The Slovak village (1938 - 1944)). Bratislava: Slovak Academic Press, 1996, 219 p. ISBN 8085665638; DOLEŽAL, Jiří. Př́íspěvek k otázkám pozemkové držby na Slovensku v letech druhé světové války. (A contribution to the questions of land holding in Slovakia in the years of the Second World War). In Československý časopis historický, 1959, year 7, p. 318-358; FIAMOVÁ, Martina. ,, Slovenská zem patrí do slovenských rúk": arizácia pozemkového vlastníctva židovského obyvatel'stva na Slovensku v rokoch 1939 - 1945. ("Slovak land belongs in Slovak hands": Aryanization of land belonging to Jews in Slovakia, 1939-1945). Bratislava: Veda, vydavatel'stvo SAV; Historický ústav SAV, 2015, 175 p. ISBN 9788022414463; RYCHLÍK, Jan. Pozemková reforma na Slovensku v letech 1940 - 1945 ve světle nových dokumenti̊. (Land reform in Slovakia, 1940 - 1945 in the light of new documents). In Védecké práce Zemédělského muzea, 1986, year 26, p. 259-263; RYCHLÍK, Jan. Príprava a priebeh pozemkovej reformy na Slovensku v rokoch 1938 - 1945. The preparation and implementation of land reform in Slovakia, 1938 - 1945). In Agrikultúra, 1989, year 22, p. 143-164. ISBN 8007001042.

2 CAMBEL, Samuel. Výsledky prvej československej pozemkovej reformy na Slovensku. (The results of the first Czechoslovak land reform in Slovakia). In Československá pozemková reforma 1919-1935 a jeji mezinárodni souvislosti : sborník př́spěvků z mezinárodní vědecké konference konané ve dnech 21. a 22. dubna 1994 v Uherském Hradišti. Uherské Hradiště: Slovácké muzeum v Uherském Hradišti, 1994 s. 51-59.

3 Hospodárska obroda, 1941, year 1, no. 1, p. 16.

4 Slovák-Týždennik, 1939, year 20, no. 42, p. 4. 
received small plots amounting to 246,777 ha of agricultural land, from the total of 298,034 ha of all the land granted to small holders. ${ }^{5}$

The course and results of the land reform during the First Czechoslovak Republic were criticized by various political groups including Hlinka's Slovak People's Party (hereinafter HSPP). Essentially, the end of the reform in the mid 1930s increased the criticism. HSPP not only demanded the distribution of the soil "to those who work on it", but also increasingly a revision of the reform, but with the exception of Church estates. In the Slovak village, the small farmers still had to deal with the same problems: great fragmentation of the land, difficult availability of land, chaotic land ownership records, a low level of mechanization, debt and a generally low standard of living. It was also impossible to satisfy all the applicants for agricultural property in the framework of the first land reform as a result of over-population of the countryside and difficult geographical conditions in Slovakia.

After the declaration of the autonomy of Slovakia in October 1938, not only the ruling HSPP, but also the general population began to call for basic change in the ownership situation in the villages, increased plant and animal production and an improved position for farmers. On 11 October 1938 the Slovak government presented measures that aimed to consolidate public and economic life in the country. They were directed especially to securing agricultural production and stabilizing the financial sector.

The situation in land ownership was summarized, for example, by the author of the article Targeted improvement of land holding to secure the future of Slovak agriculture in the January 1939 issue of the weekly Slovák as follows: "One of the main problems of Slovak agriculture... is the regulation of land holding, especially the regrouping or consolidation of plots. In most of Slovakia land holding is fragmented and property relations are very complicated. It is not unusual for a middle level farmer, who owns 10-20 cadastral yokes of land to have up to a hundred very long and narrow plots..., inaccessible from public roads and so burdened by service obligations. It is not unusual for one plot to have 10 or more joint owners. It is certainly known to everybody, who comes in contact with the land ownership register, that the real holder of a plot is often not its registered owner." 6

The Vienna Arbitration of November 1938 brought further far-reaching consequences for Slovakia. More than half a million hectares of plough soil were lost to Hungary. Such soil made up $37 \%$ of the original area of Slovakia, but

5 DOLEŽAL, ref. 1, p. 320; BAUCH, Pol’nohospodárstvo za slovenského štátu, ref. 1, p. 8.

6 Slovák-Týždenník, 1939, year 20, no. 4, p. 7. 
less than $32 \%$ of the reduced territory. ${ }^{7}$ One of the first results of the arbitration was the arrival of a large number of Slovak refugees from the occupied territory, demanding their own soil. The connected question of limitation of the land ownership of Slovaks in the lost territories and Hungarian revision of the first Czechoslovak reform led to a series of Hungarian - Slovak negotiations lasting several years. ${ }^{8}$

\section{The institutional basis for agricultural policy in Slovakia}

Solution of these problems in Slovakia demanded the building up of competent institutions. At the time of their origin, the Slovak ministries and authorities could use in some cases only the existing Slovak branches of the central authorities, and so they needed to build up their own structure and define their responsibilities in relation to the central authorities and in relation to other institutions in Slovakia. With regard to the rapid development of events in 1938 and the initial phase of formation of the Slovak state institutions, it was not possible for individual ministers to create satisfactory structures for their ministries in the course of a few weeks. This was reflected in their numerous organizational changes. The Slovak authorities could not take over the whole agenda entrusted to them in such a short time. The Minister of the Economy (hereinafter ME) or Agriculture, Trade, Public Works and Finance Pavel Teplanský established a presidium and four departments (Agriculture; Trade, Industry and Business; Public Works; Finance) by the end of October 1938. The problem of land reform fell in the framework of the Department of Agriculture Section VII. In spite of this the Prague departments still dealt with the affairs of the ministries now entrusted to the Ministry of the Economy. They did this in cooperation with their Slovak sections and with the agreement of P. Teplanský given on regular visits to Prague. ${ }^{9}$ However, the structure of this ministry and others changed in the following months. For example, from the beginning of January 1939, the whole agenda of the General Finance Directorate in Bratislava was transferred to the Finance Department of the Ministry of the Economy, so that the directorate essentially ceased to exist.

7 BAUCH, Pol’nohospodárstvo za slovenského štátu, (Agriculture in the Slovak state), ref. 1, p. $19-20$.

8 The Minister of the Economy Medrický stated in connection with the results of the first land reform: "After the Vienna Arbitration... we lost 87,344 ha of the small allocations, 2041 ha of the long-term tenancies, 21,170 ha from the colonists' land and 41,759 ha of the remnant estates making a total of 152,305 ha of the land of new acquirers. 530,000 ha remain in Slovakia." Slovák-Týždenník, 1939, year 20, no. 42, p. 4.

9 Slovenský národný archív (Slovak National Archives, hereinafter SNA), fond (collection, hereinafter col.) Ministerstvo vnútra (Ministry of the Interior, hereinafter MV), kartón (carton, hereinafter c.) 1 , no. 819/1938. 
Later in January, the Finance Department was separated from the Ministry of the Economy, to form the Ministry of Finance of the Slovak Region. ${ }^{10}$

After the election of the Parliament of the Slovak Region, President Emil Hácha appointed a new Slovak government on 20 January 1939 with Jozef Tiso continuing to hold the positions of Prime Minister and Minister of the Interior. P. Teplanský became Minister of Finance, while Mikuláš Pružinský gained the economy, or rather the Ministry of Industry, Trade and Business, and the Ministry of Agriculture. After the origin of the Slovak state on 14 March 1939, the presidium of parliament appointed the first government with J. Tiso at its head. The ministries of the economy and finance fell to Gejza Medrický and Mikuláš Pružinský.

However, from the point of view of the direction of agricultural policy it is important to analyse the structure of the Ministry of the Economy in the period starting in autumn 1938. On the basis of constitutional law no. 299/1938 Sb. z. a n. (Sbírka zákonů a nařízení, Collection of Acts and Decrees) on the autonomy of the Slovak Region, the agendas that had belonged up to 6 October 1938 to the Ministry of Agriculture and the Ministry of Trade, Industry and Business in Prague, including the still unfinished land reform, came under Slovak control. Section no. XI for land reform ${ }^{11}$ was formed in the framework of the new struc-

10 This step provoked doubts about its consistence with the consitution in places such as the Prague Ministry of Transport and the Supreme Accounts Office.

11 Section no. XI was divided into six divisions. Division XI/a was responsible for personnel, qualification and disciplinary questions concerning employees, the budget, monitoring and recording the progress of work and the work load of individual organizational units in the field of land reform. Division XI/b processed the results of internal and inter-departmental meetings for service needs, issued the appropriate instructions, inspected the state district offices, dealt with the legislative aspect of land reform, press and promotional services, monitoring the results of reform. Division XI/c administered the property of the compensation and colonization fund and the Czecho-Slovak Legionaries' Fund, supervised the fund to support the workers on large estates, the compensation bank and the bodies controlling the finances of the land reform. It also cooperated with the work of organizing assistance to recipients of land from areas especially badly affected by the economic crisis. Division XI/d was responsible for legal affairs associated with the taking over of property or disputes, setting of the take over price and its payment in agreement with the appropriate assessment division. The division also solved some problems related to enforcement proceedings on remnants of estates, enforcement of unpaid bills, setting prices of remnant properties and colonization and farming nediels. Division XI/e recorded the taking of land and applications for awards, it valued the taken over properties, devoted attention to obtaining land for the land reform, organization of the award process, selection of new owners and decisions about the awarding of remnant properties and colonization and farming nediels. It also dealt with complaints about decisions by subordinate bodies in award proceedings, setting the price for planned actions, applying Act no. 118/1920 Sb. z. a n. on regular management of taken over properties and working out expert economic assessments. The extensive responsibilities of this division also included planning of internal colonization, also carrying out award work on properties intended for 
ture of the ME. It took over the work of the IX section of the Prague Ministry of Agriculture responsible for Czechoslovak land reform. ${ }^{12}$

The activity of section no. XI determined first of all that the land reform in Slovakia was carried out more slowly and especially the collection of debt arrears for awards and their recording fell significantly behind. This involved almost 23,000 ha of land. ${ }^{13}$ Debt arrears for awards from the land reform represented a considerable amount. In October 1938 their size reached 10 million Kč (Czechoslovak crowns) only for residual estates, 15 million Kč for colonies and 65 million Kč for small awards. ${ }^{14}$

Even after the loss of the southern regions to Hungary, the debt arrears still amounted to 40 million Ks in 1942. The Ministry of Agriculture in Prague reacted to this state in connection with the expected loss of territory in southern Slovakia by attempting to accelerate the registration of the soil acquired there in the framework of land reform. This concerned some colonization nediels (a nediel was a form of agricultural plot that could support a small self-sufficient farm) in Slovakia, where, for various reasons, the ministry had not managed to submit to the appropriate courts, requests for recognition of the right of ownership of the recipients. Precisely the territorial demands of the southern neighbour stimulated the ministry to submit such requests for nediel lying in the ethnically mixed southern frontier region of Slovakia regardless of whether the price of the land had already been paid. Thus, in October 1938 the ministry produced 48 applications for award documents. To ensure the success of this action and "in the interest of the awarded land" the Ministry of Agriculture in Prague advised the Slovak Ministry of Justice to carry out the measures necessary to achieve the fastest possible registration of the land. ${ }^{15}$

colonization, selection of colonists, records of them and care for the development and appropriate economic organization of colonies. Division XI/f was responsible for the technical aspect of implementation of land reform and building work associated with it.

Section no. X of the Ministry of the Economy was the Central Directorate of State Forests and Properties. Národný archív Praha (National Archives Prague, hereinafter NA Praha), col. MV I-D, c. 76, no. 98/3.

12 The Ministry of Agriculture in Prague took over responsibility for completing the land reform of inter-war Czechoslovakia after the dissolution of the Land Office in 1935.

13 In his report to the State Council in March 1941, Karol Klinovský said that the size of the recorded awards aounted to about 40,000 ha, but other sources indicate that it was actually 40,000 cadastral yokes $(23,000 \mathrm{ha})$ of land.

14 The material for a report to the government from 1939 enumerating debts in October 1938 gives their size in Ks (Slovak crowns). SNA, col. Úrad predsedníctva vlády (Prime Minister's Office, hereinafter ÚPV), c. 241, no. 40.

15 SNA, col. Ministerstvo hospodárstva (Ministry of the Economy, hereinafter MH), c. 931, no. $793 / 1938$. 
At the same time, the Ministry of the Economy also had to solve the abovementioned question of refugees from Hungary. In an effort to deal with pressure from them and the problems connected with it, the Slovak government decided soon after the Vienna Arbitration that the foreign colonists evacuated from the lost territories should be deported to the countries from which they originated. At the same time, however, the land reform division at the ministry received a further agenda. According to a government decree, interested people had to apply to exchange their property. This applied to owners from the occupied territories with property in Slovakia and the reverse. ${ }^{16}$

The mass arrival from the occupied territories of colonists, often regarded with dislike by the Slovak population, caused considerable difficulties for the Slovak government. The arrival of evacuees provoked tension in various places. For example, the HSPP member of the National Assembly Roman Catholic priest Anton Šalát demanded at the beginning of November 1938 that the Slovak government should quickly send a government commissioner to the Vígl'aš estate, where he said there was a threat of a workers' revolt.

The cause was supposed to be the placing of Czech colonists in the workforce and the alleged effort of the director to dismiss the "old employees". "Settle the situation quickly or it will be bad", as he appealed to the prime minister. In reaction the government leadership asked the chief district official in Zvolen to personally investigate the matter. However, according to his information the revolt did not happen and the colonists or legionaries remained there until the end of November 1938, when after taking horses, they left the territory of Slovakia ${ }^{17}$

During the temporary placing of refugees on estates, section XI of the ME helped and later carried out the first of the government decrees after the establishment of the Slovak state: decree no. 5/1939 Sl. z. (Slovenský zákonník, Slovak Statute Book) from 15 March 1939 on the transitional securing of small farmers' land for refugees by means of the internal tenancy on properties exceeding 50 ha. $^{18}$

However, in this case the section had only about 20,000 ha of land available, which was certainly not enough to satisfy all the interested people. For this reason, it granted tenancies only to persons of Slovak or German nationality, who had larger families, livestock and equipment. Persons, who were not farmers before the awards, did not lead a moral life, had no children, had not personally done business in Hungary or could support themselves in other ways, were

16 Slovenská pravda, year 3, no. 181, 9 Nov 1938, p. 1.

17 SNA, col. MH, c. 931, no. 635/1938.

18 Placing of farmers from areas occupied by a foreign power in properties exceeding 50 ha was already approved by Decree of the Czechoslovak Government no. 304 from 25 Nov 1938. 
excluded from selection by the section. By November 1939, three year tenancies had been granted to 798 families. ${ }^{19}$

Apart from these tasks, the Ministry of the Economy also provided so-called general agreements, ${ }^{20}$ approved all dispositions of farmers' nediels (according to the Distribution Act), solved appeals against decisions of the state district offices and administered the three land reform funds: compensation, colonization and the Fund for employees of former landowners. However, in the case of this agenda, the ministry struck against the reality that important files concerned with land reform in Slovakia remained in Prague. The expected division of files with the aim of solving problems in this area did not happen even after the origin of the Slovak state.

\section{The preparation of changes to land ownership}

The question of the reform of land holding in Slovakia, so important for the representatives of the new regime, already began to be solved soon after the declaration of autonomy in autumn 1938. For example, the request of the head of section VII of the Department of Agriculture of the ME František Ševčovič from 1 November 1938 to the Ministry of Foreign Affairs on the provision of information "about the method of reforming land holding arrangements in agricultural settlements" in Germany, testifies to this. The ministry was very interested in the principles of German legislation in this field and the results of its application in practice. ${ }^{21}$ Specific proposals to improve the intolerable situation in the field of land ownership already appeared at the beginning of 1939 in the declarations of various Slovak politicians. Ferdinand Durčanský, a member of the Commission for Solving the Jewish Question in Slovakia (the so-called Sidor Committee) proposed a decree of the government of the Slovak Region on partial reform of ownership and holding of landed property in Slovakia by excluding the Jewish minority from land ownership..$^{22}$ According to supplementary information to the government decree on land reform, revision of the previous land reform with the aim of building up independent indivisible farms had to be an instrument for "satisfying land hunger". ${ }^{23}$ The need to revise land reform was also mentio-

19 SNA, col. ÚPV, c. 241, no. 40; SNA, col. MH, c. 43, no. 704/39 - XI/dôv.

20 General agreements were agreements on the implementation of land reform concluded by the Land Office with the owners of large estates in the time of the First Czechoslovak Republic.

21 SNA, col. MH, c. 931, 1628/P/1938

22 NIŽŇANSKÝ, Eduard. Holokaust na Slovensku. Obdobie autonómie (6. 10. 1938 - 14. 3. 1939). Dokumenty. (The Holocaust in Slovakia. The period of autonomy (6 Oct $1938-14$ March 1939). Documents.). Bratislava: Nadácia Milana Šimečku, 2001, document no. 60, p. 130-143. ISBN 8096862057.

23 DOLEŽAL, ref. 1, p. 330; SNA, col. MH, c. 4, without no. 
ned by Prime Minister Jozef Tiso in the Parliament of the Slovak Region in his programme declaration of February 1939, where he argued for removal of the "injustices" of the first land reform "and to put the land in the hands of those who really worked on it". ${ }^{24}$ In mid February 1939, during a joint meeting of the Slovak and central governments, Minister Pružinský stated his view of the programme of the Ministry of the Economy.

In connection with the planned reform of land holding, he emphasized the need "to correct some faults of the land reform". In his view, land "had to stop being an opportunity for speculation and its price would be controlled". Land had to pass "only into reliable Slovak hands. An action in this direction is being prepared. The Regional Bank will buy land and then sell it". The plan also included reform of the land registers, consolidation of plots, reform of inheritance rights, preparation of the institution of economic chambers as corporate organizations and other measures. ${ }^{25}$

After the declaration of the independent Slovak state in March 1939, it was not long before legal norms paved the way towards substantial changes in land ownership. At the end of March 1939, the government already decreed that the district offices had to begin transitional supervision and enforced administration of properties amounting to more than 30 ha, which, in the end, meant mainly Jewish properties. In April the government issued a decree on politically enriched people no. 73/1939 Sl. z., which meant the confiscation of properties acquired thanks to political activities from 30 October 1918 to 6 October 1938. Concrete decision-making was entrusted to a five member commission appointed by the government on the basis of a proposal from the Ministry of the Interior. Only the government would be able to change its decisions. ${ }^{26}$ Compulsory registration of Jewish owned land (decree no. 147/1939 Sl. z. from 21 June 1939) and land owned by foreign citizens (decree no. 146/1939 S. z.) followed. This was associated with substantial limitation of property rights, because such property could not be sold, mortgaged or let without permission from the Ministry of the Economy.

A decree on the frequently mentioned revision of the first land reform was adopted in October 1939. On the basis of its provisions, the Ministry of the Economy had to re-evaluate the measures and decisions of the State Land Office and Ministry of Agriculture during the period of the inter-war Czechoslo-

24 Shorthand report on the second session of the Parliament of the Slovak Region in Bratislava on 21, 22 and 23 Feb 1939 [online]. Accessible on the internet: http://www.psp.cz/ eknih/1939ssk/stenprot/002schuz/s002001.htm

25 Slovák, 1939, year 21, no. 42, p. 4.

26 Slovenský zákonník, 1939, Vládne nariadenie č. 73/1939 Sl. z. o politických zbohatlíkoch (Government decree no. 73/1939 Sl. z. on the politically enriched). 
vak Republic. ${ }^{27}$ Section XI of the ME then started the revision of the remnant properties preliminarily awarded to foreigners, as well as preparation to revise the confiscation of empty properties on the basis of $\S 7$ of the Abalienation Act and $\S 20$ of the Distribution Act. ${ }^{28}$ According to the Minister of the Economy G. Medrický, the revision of the land reform had to remove "the most blatant errors committed by the former regime" and so prepare the way for a new reform. He expressed its principles as follows: "The soil of Slovakia belongs in the hands of the small Slovak farmers. Those who work on the land have the right to own it. The Jews will gradually be entirely excluded from land ownership. Our aim in the framework of this new land reform is to create independent farms with an average size of $30 \mathrm{ha}$, from which the farming class will be able to derive its economic strength." 29

According to the head of section XI of the ME František Ševčovič: "The great effort to obtain land forced section XI to accept justified demands even before the issuing of the proposed legislation on reform of land holding." Starting from this position, 994 ha of Jewish land (declared on the basis of government decree no. 147/1939 Sl. z.) and 93 ha of land belonging to foreigners passed into the hands of "Aryans" up to November 1939 as a result of approval of purchase contracts by the Ministry of the Economy. 5,622 ha of confiscated land also changed owner..$^{30}$ However, at this time the Ministry of the Economy was not fulfilling only the above mentioned duties, it was also playing an active part in preparing changes to land holding in Slovakia. The reason was not only the generally proclaimed need for agricultural land to pass "into the hands of the working Slovak farmers".

The need to fulfil orders to deliver plant and animal products to Germany according to the provisions of the Treaty of Protection, also played an important role here. With regard to the low level of Slovak agricultural production and the backwardness of the countryside, the new land reform was expected to bring a break through towards modernization. ${ }^{31}$

27 Slovenský zákonnik, 1939, Vládne nariadenie č. 253/1939 Sl. z. o revízii pozemkovej reform (Government decree no. 253/1939 Sl. z. on revision of land reform). This government decree was cancelled by Act no. 46/1940 Sl. z.

28 This had to apply especially to people prominent under the old regime and to foreigners. SNA, col. MH, c. 43 , no. $704 / 39-$ XI/dôv.

29 Slovák, 1940, year 22, no. 8, p. 3.

30 SNA, col. ÚPV, c. 241, no. 40; SNA, col. MH, c. 43, no. 704/39 - XI/dôv.

31 HALLON, Ludovít - SABOL, Miroslav. Zlaté roky hospodárskeho vývoja Slovenskej republiky 1940 - 1943. (The golden years of economic development of the Slovak Republic 1940 - 1943). In SOKOLOVIČ, Peter (ed.). Od Salzburgu do vypuknutia Povstania. Slovenská republika 1939 - 1945 očami mladých historikov 8. Bratislava: Ústav pamäti národa, 2009, p. 411-412. ISBN 9788089335213. 
The actual government proposal for legislation on reform of land holding was prepared by a special commission appointed soon after the declaration of the independent state by the Minister of the Economy Gejza Medrický. National economists such as P. Zat'ko, I. Karvaš and the former agrarian V. Moravčík also participated in conceiving the philosophy of the new land reform. ${ }^{32}$ In November 1939, the head of section XI František Ševčovič evaluated the aims of the ministry: "The Ministry of the Economy has identified the question of land holding as a basic programme for building the state. For this reason it has established an office to solve this question and prepare the necessary legislation. "33 Minister Medrický stated the following on preparation of the legislation in October 1939: "Immediately after taking office, we especially encountered the question of Jewish land and the questions of the land placed in the hands of people hostile to Slovak national and state thinking. Our first task after 14 March was to stop the further transfer of Slovak land into hostile hands." Therefore, the Ministry of the Economy wanted its proposed legislation on land reform "to achieve a solution of the question of Jewish land, the question of the revision of the old Czechoslovak land reform and the question of the regular transfer of land into reliable hands". ${ }^{34}$

The main method of acquiring land for the state had to be the purchase of Jewish and non-Jewish land or land in the hands of foreigners. The act had to ensure the distribution of landed property "in favour of the national and economic unit" and to bring ownership "to the group with a more sincere relationship to the land, the group of working small farmers". ${ }^{35}$ The acquired land had to pass "into the hands of nationally reliable citizens of the state, the hard-working and expert". ${ }^{36}$

\section{"The most revolutionary Slovak act"}

Preparation of the new land reform culminated on 22 February 1940, when the Slovak Parliament passed Act no. 45/1940 Sl. z. on establishment of the State Land Office (hereinafter SLO), although in reality this office was formed by only reshaping section XI of the ME. It was subject directly to the government and

32 Ibid., p. 412.

33 SNA, col. MH, c. 43 , no. 704/39 - XI/dôv.

34 Slovák-Týždenník, 1939, year 20, no. 42, p. 4.

35 SNA, col. MH, c. 43, no. 704/39 - XI/dôv. PODOLEC, Ondrej. Perzekúcie a právny poriadok na Slovensku v rokoch 1938 - 1945. (Persecution and the legal order in Slovakia, 1938-1945). In SOKOLOVIČ, Peter (ed.). Perzekúcie na Slovensku v rokoch 1938 - 1945. Slovenská republika 1939 - 1945 očami mladých historikov 7. Bratislava: Ústav pamäti národa, 2008, p. 29-30. ISBN 9788089335084.

SNA, col.. MH, c. 43, no. 704/39 - XI/dôv. 
its task was to administer the property that fell to the state in the course of the reform, and to decide about specific awards and purchases of land. ${ }^{37}$ The Land Reform Act no. 46/1940 Sl. z. ${ }^{38}$ originated on the same day as the Act on the SLO. It set the methods of acquiring agricultural properties, their administration, assignment and granting of credit to the new owners. ${ }^{39}$ According to a statement in the Slovák newspaper, the Land Reform Act was "the most revolutionary act of the Slovak political representatives in the independent Slovak state. It is the most beautiful fruit of our political work, the culmination of Slovak wishes from the time of Śtúr until today". ${ }^{40}$ The member of parliament Miloš Vančo also expressed excessive optimism: "States change and regimes as well, everything changes, but the really important thing is that a good land reform will survive changes of regime." ${ }^{41}$

The act had a clearly anti-Jewish character already reflected in its justifying report, according to which the compulsory purchase of Jewish land was justified by the argument: "that the Jews mostly acquired their land by a method incompatible with the principles prevailing in the Slovak Christian state. In addition, the Jews do not work the land themselves and regard it only as a way of storing money..." "42

The act decided that the state could obtain land for the needs of the reform by purchasing abalienation properties of more than 50 ha (or parts), taken over in judicial sale, purchase from foreign citizens ${ }^{43}$ regardless of size, purchase from Jews and revision of decisions of the SLO in Prague and Ministry of Agriculture in Prague taken on the basis of act no. 215/1919 Sb. z. a n. However, in the case of Slovak citizens it did not apply to awards of up to 10 ha or to the property of recognized and received Christian churches and charities. The State Land Office had the right to purchase all agricultural land belonging to Jews, which was subject to registration according to government decree no. 147/1939 Sl. z. ${ }^{44}$ for an

37 SNA, col. ÚPV, c. 241, no. 618/1940; Slovenský zákonník, 1940, Zákon (Act) no. 45/1940 Sl. z. o Štátnom pozemkovom úrade (on the State Land Office).

38 Both acts became valid on 13 March 1940.

39 Slovenský zákonník, 1940, Zákon č. 46/1940 o pozemkovej reforme (Act no. 46/1940 on land reform).

40 Slovák, 1940, year 22, no. 47, p. 1.

41 Slovák, 1940, year 22, no. 44, p. 1.

42 Report from the third meeting of the National Economic Committee of the Parliament of the SR on 9 Oct 1939. I thank E. Nižňanský for providing the document.

43 On the basis of reciprocity, the act allowed foreigners to acquire agricultural property on the same conditions as Slovak citizens and only with the agreement of the State Land Office (hereinafter SLO). Slovenský zákonnik, 1940, Zákon č. 46/1940 o pozemkovej reforme (Act no. 46/1940 on land reform).

44 This provision of the Land Reform Act was repealed by government decree no. 56/1941 Sl.z. 
estimated price determined by the appropriate state district office for land reform or regional court. ${ }^{45}$ The state had to pay the purchase price for the properties of Jews and foreigners according to the act with interest of $3 \%,{ }^{46}$ but Jews and foreigners could not get this money in cash. To prevent them taking their money abroad, the SLO deposited the purchase price in so-called compensation books as state debt. Payment of the purchase price in cash was possible only in cases "where there is no danger of export of the money" or in serious social cases. ${ }^{47}$

After Act no. 46/1940 Sl. z. became valid, a Jew could not gain any permanent right to agricultural property except in the case of legal inheritance ${ }^{48}$ and could not conclude new tenancy agreements. Already existing agreements had to be cancelled within three years. The SLO had to award land to small farmers or to workers, craftsmen and persons "who deserve an award from the social point of view". They had to be "morally preserved" Slovak citizens of the Christian religion, who, thanks to the reform, could build up independent farms capable of supporting a farmer and his family. It was supposed to involve educated small farmers, employees of parcelled estates (by application of tenancy arrangements ${ }^{49}$ ), both local small farmers and refugees or colonists..$^{50}$

The Land Reform Act divided awards of land into agricultural and non-agricultural categories. While agricultural awards included areas of 6-15 ha for family farms ${ }^{51}$ supplementary awards up to the size of the family farm and awards

from March 1941, according to which all agricultural properties of Jews were subject to purchase. This decree also extended compulsory purchase to the land of Jewish corporate bodies with which the Land Reform Act was not concerned.

45 Slovenský zákonnik, 1940, Zákon č. 46/1940 o pozemkovej reforme (Act no. 46/1940 on land reform). Setting of the estimated price of the purchased property was clarified by government decree no. 206/1940 Sl. z. from 17 Aug 1940.

46 SNA, col. ŠPÚ, c. 3, 198/42 účt.

47 Tlač $1-6$ Snemu Slovenskej republiky, 1. volebné obdobie, 2. zasadanie. Dôvodová správa k zákonu o úprave pozemkovej držby. (Proceedings 1-6 of the Parliament of the Slovak Republic. $1^{\text {st }}$ electoral period, $2^{\text {nd }}$ session. Explanatory report on the Land Reform Act).

48 Preserving the right of Jews to inherit land was motivated by the fact that in the opposite case, the SLO would have had to purchase the given property immediately without regard for the public interest or the possibility to sell it to anybody else.

49 The Land Reform Act enabled some applicants to obtain land by means of the so-called award of tenancies. Government decree no. 193/1941 Sl.z. from August 1941 also identified persons, who could obtain awards in this way. The decree widened the category of applicants to include men injured in the war and professional non-commissioned officers, but they had to do agricultural training courses, people trained in economic schools, and small farmers with at least five unsupported children.

50 DOLEŽAL, ref. 1, p. 334.

51 The rules on agricultural nediel from the inter-war Czechoslovak land reform related to the awards of family farms. 
of up to 30 ha, non-agricultural awards meant areas of less than 6 ha for industrial or practical enterprises or as building plots. ${ }^{52}$ An applicant could gain an award only if he paid half its price to the account of the Land Reform Fund..$^{53}$

But how much land did the new government really have available? It is necessary to say that at the time of passing Act no. 46/1940 Sl. z. the Slovak representatives did not have a clear idea of the resources available for the reform to which they attached such great hopes. According to the Minister of the Economy Gejza Medrický, the land reform had to include 800,000 ha of "Aryan soil" above 50 ha (300,000 ha of it cultivated), 241,598 ha of land of foreign citizens $\left(61,877\right.$ ha of it cultivated), ${ }^{54} 476,000$ ha from revision of the first land reform (226,000 ha of it cultivated), and 101,410 ha of Jewish land (44,371 ha of it cultivated).$^{55}$ The land reform was expected to cover 631,000 ha of cultivated land and 987,000 ha of forest. ${ }^{56}$

52 Slovenský zákonník, 1940, Zákon č. 46/1940 o pozemkovej reforme (Act no. 46/1940 on land reform).

53 Slovenský zákonník, 1940, Zákon č. 46/1940 o pozemkovej reforme (Act no. 46/1940 on land reform). However, the government proposal for the act originally demanded that the recipient of an award should pay up to $75 \%$ of the price. The other half of the price would be paid over 40 years.

54 On the basis of government decree no. 146/1939 Sl. z. on the registration of agricultural property of foreigners, it was found that 2,012 Hungarian citizens owned a total of 118,582 ha, while 2,334 other foreigners owned 105,314 ha. However, other information from the SLO stated that this register included the property of 3,998 persons, who owned 235,738 ha. SNA, col. ÚPV, c. 241, Referát Jána Balka o činnosti ŠPÚ (Report by Ján Balko on the activities of the SLO); SNA, col. MH, c. 965, Štatistika pozemkovej reformy (Land reform statistics).

55 However, information about the extent of Jewish land varies. Ján Balko, a member of the State Council, said that the Jewish property registered according to government decree no. $147 / 1939$ Sl. z. amounted to 44,372 ha of agricultural land, 45,883 ha of forest and 11,168 ha of other land, making a total of 101, 423 ha belonging to 4,693 Jews. During evaluation activities by the State Land Office in 1941, its chairman Karol Klinovský appealed to the same source. According to him, Jews owned 44,771 ha of Slovak agricultural land, 37,640 ha of forest and 8,902 ha of other land. In May 1942 Karol Klinovský sent Ambassador Jozef Mračna a report on the implementation of the land reform in relation to Jewish property, in which he stated that in the territory of Slovakia 3,473 agricultural and forestry businesses with an area of 87, 117 ha were in Jewish hands (according to decree no. 147/1939 Sl.z.), while 270 Jews were tenants of middle sized and larger agricultural properties. According to the report, 3,500 persons (without family members) from a total of 85,000 Jews were active in agriculture. Another SLO document from May 1942 mentions a number of 304 Jewish tenants in Slovakia. SNA, col. ŠPÚ, c. 10, no. 59/42 os, c. 24, Zoznam židovských nájomcov pôdy (List of Jewish tenant farmers). NIŽŇANSKÝ, Eduard - KAMENEC, Ivan. Holokaust na Slovensku 2. Prezident, vláda, Snem SR a Štátna rada o židovskej otázke (1939-1945). (The Holocaust in Slovakia 2. The President, government, parliament and State Council of the SR on the Jewish question (1939-1945)). Bratislava: Nadácia Milana Šimečku, 2003, document no. 11, p. 40. ISBN 8096866222; BAUCH, Pol’nohospodárstvo za slovenského štátu, ref. 1, p. 26.

56 Parliament of the Slovak Republic 1940, shorthand report from $26^{\text {th }}$ session on 22 February 
In contrast to these ideas of G. Medrický, the SLO later estimated the extent of the land gained from revision of the first land reform as only 17,264 ha and the land of foreigners as about 34,530 ha. Thus the SLO could count on about 145,000 ha of plough and forest soil for the needs of the land reform. It also had control over property estimated at 2,027,318 ha confiscated from Slovak citizens with more than 50 ha. ${ }^{57}$

According to the statistics, Slovakia had a total of 4,894,585 ha of land from which $1,065,141$ ha were lost as a result of the Vienna Arbitration. Slovakia still had 1,193,388 ha of fields, 298,313 ha of meadows, 16,198 ha of gardens, 6,740 ha of vineyards, 475,586 ha of pastures, 1,460,570 ha of forest soil, 54,364 ha of land with buildings, 233,405 ha of other infertile land and so on. ${ }^{58}$ The proportion of land owned by Jews in proportion to all the land in the state (more than 3.8 million ha) was only $2.24 \%$, while the land owned by foreigners amounted to $6.20 \% .^{59}$

At the time the Land Reform Act was passed, this question began to be considered more intensively in the pages of the press. Apart from the political representatives, members of expert circles also explained the aims of the new legislation to the public. For example: Michal Sahulčík, later head of the presidium of the SLO, stated: "Our land reform not only reforms land holding in relation to particular complexes... it to some degree reforms our whole legal relationship to land, and from the national economic point of view, it mobilizes the soil in favour of increased national production... Today, every transfer of land must be done in a rational way. Every change of land ownership must be justified by the higher interests of the economy and cannot remain outside the intervention of economic regulation." $" 60$

However, the enthusiastic statements of the Slovak political representatives on the benefits of the new land reform quickly aroused expectations of wide access to land among the small farmers of Slovakia on the basis of the Land Reform Act. Therefore, at the beginning of March 1940, M. Sahulčík already had

1940, p. 4.

57 BAUCH, Pozemková reforma, ref. 1, p. 374; SNA, col. MH, c. 965, Štatistika pozemkovej reformy.

58 Member of parliament Turček at a session of the Parliament of the SR stated that after the loss of the southern districts to Hungary, 2,103,000 agricultural properties remained in Slovakia. From the point of view of size, $19 \%$ had up to 5 ha, $46 \%$ had $5-30$ ha and $35 \%$ had more than 30 ha. Výmera kultúr v pôvodných a terajších hraniciach Slovenska. (Size of farms in the original and present frontiers of Slovakia.). In Slovenská politika, 1941, year 22, no. 69, p. 5. Parliament of the Slovak Republic 1940, shorthand report from the $26^{\text {th }}$ session on 22 February 1940, p. 4.

59 SNA, col. MH, c. 965, Štatistika pozemkovej reformy.

60 Slovák, 1940, year 22, no. 44, p. 1. 
to damp down the wishes of the people. In an article: The land will not be given away for free, he stated that "the new Land Reform Act has stimulated many inaccurate interpretations of the aims and programme of land reform... A person who acquires land easily or cheaply does not value it, does not work on it and usually relies on somebody else's work... Some think that the Jews will lose their land without compensation, so the state will give it away for free. It was not possible to confiscate this land because there was no accepted reason for this, not even the reason that the Jew got the land in return for drink. It would be difficult to judge who has greater fault, the Jew, or the man who drank his land... The fact is that the Jewish land will be bought, but also not without planning... This means that where there is a well cultivated and prospering Jewish farm, where the Jew is doing exemplary business... it will not be thoughtlessly bought and distributed because that would disturb the whole economy of the district... Some of these farms will have to be transferred complete into the hands of new Christian owners ". ${ }^{11}$ The report of the head of the State Land Office F. Ševčovič to the club of HSPP members of parliament in mid March 1940 had an equally sober tone: "There is a strong effort under way to get the land divided into impossibly small awards, the fate of which is already well known to us from the old land reform... It is in the interests of the state that the land to be distributed should be awarded to non-farmers only in cases where this will not damage the national economy or reduce the productive capacity of the land... We want to apply the principle that applicants with irregular employment are not tied to particular villages by awards of land, that we do not create a new village proletariat." 62 Such statements may have caused confusion in the minds of some people about the newly enacted land reform. Therefore, at the beginning of April, the Slovák newspaper considered it necessary to reassure people and already promise in the headline that: Those with no money will also get land. The land reform does not have only economic, but also social aims - We must make the poor into self-confident citizens and proud patriots. According to the author: "Our land reform will be viewed by the public in two ways, economic circles or at least those that measure all political activity in material terms, consider our land reform only as something directed towards economic prosperity... The Slovak public and especially the broad masses look at land reform as a purely social problem. They assess it more according to spiritual than material values." In reaction to the declaration "that land will not be given away free" the author pointed to the possibility of tenancies established by the act and a little over simply stated that: "The Land Office will give land and money for buying agri-

61 Slovák, 1940, year 22, no. 54, p. 4.

62 Slovák 1940, year 22, no. 63, p. 7. 
cultural necessities both living and non-living." The conclusion of the article admits the economic reasons for larger properties: "there will be better profits and so on," "... but this opens the way to the proletarianization of the nation, creating a nation of wandering workers and that is the road to real Bolshevization... Recent and earlier history proved very clearly that the independent small and middle sized farmer is the best support for nationalism or the state, that he is the true bearer of tradition on his father's land". ${ }^{63}$

\section{The activity of the State Land Office}

Apart from the Land Reform Act, other legal norms to regulate the new land reform process were passed in 1940. According to Act no. 176/1940 Sl. z. from July 1940 on amending the Land Reform Act, anybody who gave up possession of property with an area of more than 50 ha or its part had to apply for permission from the SLO, which significantly deepened its right to purchase land. In September 1940, the Slovak Parliament passed an act on purchase of property bought by Jews at enforced auctions. It allowed the original non-Jewish owner or his heir to buy back the property from the Jew, who acquired it in an enforcement auction at the original price. ${ }^{64}$

After it was established, the State Land Office had to concern itself not only with the problem of the new reform, but also with completing the procedures derived from the first land reform and with care for the refugees and colonists from the territories occupied by Hungary. In an effort to solve their situation, the SLO placed 1012 refugee families in properties larger than 50 ha. In the first year of its existence the office also had to put considerable energy into ensuring that in the case of the majority of Jewish properties (published in the Úradné noviny (Official News) from 1940) a note was placed in the land registers by the courts stating the intention to take over the properties. The valuation of properties according to government decree no. 206/1940 Sl. z. began only in some places, but the SLO also devoted its attention to placing forced administration according to decree with the force of law no. 240/1940 Sl. z. on properties that were to be purchased according to the land reform. The office proposed it to the appropriate courts in the case of properties that were inadequately exploited or in danger of not being used.

From the land registered according to government decrees no. 146/1939 Sl. z. and no. 147/1939 S1. z., the State Land Office authorized sale in 232 cases of

63 Slovák, 1940, year 22, no. 77, p. 3.

64 According to J. Doležal, Jewish land passed into Christian ownership on the basis of the Buy Back Act (no. 213/1940 Sl.z.) in 226 cases in 1941 and in 12 cases in 1942. DOLEŽAL, ref. 1, p. 348. 
9,262 ha, including 2,659 ha of Jewish land in the first year of the land reform. According to data from the chairman of the office Karol Klinovský from June (?) 1941, there were already 302 cases (4,283 m ha) allegedly concerning only Jewish land, but this appears improbable for the time. ${ }^{65}$ A further 25,299 ha of Jewish land was found in the purchase proceedings. ${ }^{66}$ The rest were still in the hands of their original owners, at least formally, but the larger Jewish agricultural enterprises were placed under compulsory administration. ${ }^{67}$ According to K. Klinovský's data from mid May 1941, the SLO authorized the confiscation of land owned by Hungarians according to $\S 19$ of the Land Reform Act ${ }^{68}$ in 33 cases amounting to 12,547 ha. A total of 24,232 ha of land in 98 cases belonging to foreigners regardless of nationality changed hands by free sale on the basis of approval by Section XI of the ME or the SLO up to May $1941 .^{69}$

The slow implementation of the land reform during the first year after passing of act no. 46/1940 Sl. z. is also shown by the fact that the first purchase and distribution of Jewish land according to its provisions was carried out by the land office only in April 1941 in the territory of Čeklís, ${ }^{70}$ where eight Jewish properties, four of them jointly owned with Christians, with a total area of 163 ha were divided between 84 applicants. ${ }^{71}$ This led to the creation of five family farms with a total area of 65 ha, plots of 15 ha for two colonist families, and 5 ha for public building purposes. The other recipients included nine former owners,

65 SNA, col. ÚPV, c. 241, Referát Jána Balka o činnosti ŠPÚ (Report by Ján Balko on the activities of the SLO); DOLEŽAL, ref. 1, p. 334.

66 KAMENEC, Ivan. K hospodárskej politike slovenskej buržoázie v rokoch 1939 - 1945: arizačný proces a jeho triedny charakter. (On the economic policy of the Slovak bourgeoisie in the period 1939-1945: the Aryanization process and its class character). In Historické štúdie, 1977, year 22, p. 54.

67 Ibid.

68 "Acquisition of immovable property of foreigners by purchase. (1) The State Land Office can apply its right to purchase any agricultural properties without regard to their area also when they are not transferred according to $\$ 3$, if the owner is a foreign citizen, and by the method, to the extent and for the reasons applied in his state. (2) The State Land Office must not apply this right when a citizen of the Slovak state is buying the property, or when a property in a foreign state is exchanged for a property in Slovakia. The State Land Office will confirm this decision in accordance with $\xi 5$ and take from the owner a contribution of 5\% of the value of the property for the fund according to $\$ 50$ of this act. The basis for charging this contribution is the price stated in the purchase and sale contract, or the estimated price in the case of exchange."

69 SNA, col. ÚPV, c. 241, Referát Jána Balka o činnosti ŠPÚ (Report by Ján Balko on the activity of the SLO).

70 Now Bernolákovo.

71 SNA, col. ŠPÚ, c. 23, Správa o organizácii a celkovej činnosti ŠPÚ (Report on the organization and general activities of the SLO). 
who received 10 ha, seven tenants who got 9 ha, 8 joint owners who got 5 ha and seven neighbours of the purchased property, who received 8 ha. The remaining 61 ha of the land was divided into small awards for 47 applicants. ${ }^{72}$ In April 1941 the SLO also carried out a definitive division of land in Kozárovce on the remainder of the estate of F. Kadečka (118.5 ha). The property was one unit, but 11 family farms with a size of 11.5 ha were formed from it. In April 1941 the office took over by an enforced sale according to the Land Reform Act the property of the Jewish Timföld brothers in the territory of Skalica with an area of 7.5 ha. It was then handed over "to the ownership and use" of two applicants. Jewish properties in the territory of Klobušice including an estate with an area of 165 ha were purchased by May. ${ }^{73}$

This information shows that the progress of the SLO in the first year after its establishment and the implementation of land reform in this period could not satisfy the public calling for rapid purchase and distribution of land. The Slovak government also had to take into account the ideas and aims of the other decisive player in the field of the Slovak economy - Nazi Germany.

The coming to Slovakia of the German adviser on agriculture and land reform Hans Hamscha in autumn 1940 underlined the importance of supervising the development of domestic agriculture. According to him: "The work of the land office and the implementation of land reform had greater importance for the German Reich than is generally supposed, because if the reform is carried out in the old Czech spirit, which means only to gain popularity for the Slovak government by handing over land to anybody and in any extent, it may lead to reduced production, which may also be unfavourable for the Reich. " 74 From the point of view of the German adviser it was desirable to achieve in Slovak agriculture an equal division between small, middle-sized and large agricultural enterprises. Especially when dividing Jewish land, the state had to remember that it should not create further fragmentation of agriculture. On the contrary, it must expand farms that were not viable, at least to a size of $7-8$ ha. ${ }^{75}$ It did not correspond entirely to the truth when he stated that he had led the SLO to follow the principle that the land reform should not increase the "agricultural proletariat", but should enlarge the small properties of farmers to an adequate level. ${ }^{76}$ The text of the Land Reform Act no. 46/1940 Sl. z. from 22 February 1940 clearly stated that

72 NIŽŇANSKÝ - KAMENEC, ref. 55, document no. 35, p. 125.

73 Ibid.-

74 Bundesarchiv Berlin (hereinafter BArch), col. R 70 Slowakei, no.128, Der Berater für Landwirtschaft und Bodenreform, 27 March 1941.

75 BArch Berlin, col. R 70 Slowakei, no. 128, Der Berater für Landwirtschaft und Bodenreform, 22 Jan 1941 and 27 March 1941.

76 SNA, col. 116-25-1/127-136. 
farmer's awards had to include land with an area of 6-15 ha the so-called family farm, supplementary awards up to the size of a family farm and awards of up to 30 ha. Thus, from the beginning, the Slovak representatives did not intend to enlarge the ranks of the "agricultural proletariat". ${ }^{77}$

According to the German adviser, it was necessary for the reform to preserve the integrity of Jewish estates and Aryanize them without significant sub-division. Therefore, in practice, the state should sell land only to farmers whose properties would really represent "healthy agricultural businesses". Opposition to the division of larger properties arose on one side from German fears of the possible negative impact on agricultural production (,,Hier, ebenso wie in einer eventuellen Aufteilung der jüdischen Grossbetriebe ,um jeden Preis ' liegt eine grosse volkswirtschaftliche Gefahr, vor der nicht genug gewarnt werden kan$n ! ! ! ! ! ! "),{ }^{78}$ but on the other, the German side "foresaw" that land in the form of larger economic units is "more easily accessible" ("leichter greifbar") than in the form of innumerable small plots. The bringing of such tiny units into German hands could cause a multitude of social problems as well as political difficulties. $^{79}$

At the beginning of 1941 dissatisfaction with the work of the SLO led to the German adviser proposing that its chairman František Ševčovič should be replaced and the Prime Minister Vojtech Tuka willingly agreed. ${ }^{80}$ However, the head of the financial section of the SLO František Lednár ${ }^{81}$ supported by Hamscha did not gain the leading position. The Prime Minister's Office soon filled the top position at the SLO. A decree from 27 February 1941 entrusted the post to Karol Klinovský from the staff of the Foreign Ministry, who took up the position on 1 March 1941. However, the replacement of František Ševčovič with Klinovský finally proved to be "eine verlorene Schlacht" 82 from the point of view of the German adviser because he considered both the old and the new heads of the State Land Office ,,gleichermaßen deutschfeindlich... [Klinovský] jedoch wegen seiner ,Schlauheit und Hinterlistigkeit... in seiner Gefährlichkeit Ševčovič noch

77 Slovenský zákonník, 1940, Zákon č. 46/1940 o pozemkovej reforme (Act no. 46/1940 on land reform).

78 "There is great danger to the national economy here, just as in the case of the division of large Jewish companies "at any price”. It is impossible to warn against it enough!!!!!!” BArch Berlin, col. R 70 Slowakei, no. 128, Der Berater für Landwirtschaft und Bodenreform, 22 Jan 1941.

79 BArch Berlin, col. R 70 Slowakei, no. 128, Der Berater für Landwirtschaft und Bodenreform, 27 March 1941.

80 TÖNSMEYER, Das Dritte Reich und die Slowakei, p. 220.

81 BArch Berlin, col. R 70 Slowakei, no. 128, Der Berater für Landwirtschaft und Bodenreform, 22 Jan 1941.

82 "a lost battle". 
übertrifft " ${ }^{83} \mathrm{He}$ did not trust Klinovský from the beginning, describing him as "entirely inexpert" and hostile to the Germans. He regarded the personnel change as "regrettable". ${ }^{84}$ At the end of March he already stated that he felt "rather unhappy" and helpless where Klinovský was concerned.

Almost immediately after taking office, Karol Klinovský began to reorganize the SLO so that its structure would be more suited to the quickest possible transfer of Jewish property into "Christian hands". Almost a year after the passing of act no. 46/1940 Sl. z. it was clear that obstacles to the more rapid progress of land reform flowed from the provisions of the act itself. The effort to accelerate reform of Jewish property in May 1941 ended with the adoption of decree no. 93/1941 Sl. z., which originated from the SLO. However, according to Hamscha it was actually his proposals, which were accepted by the Slovaks, that contributed to the acceleration. ${ }^{85}$ It is true that implementation of reform accelerated only after the arrival of the new head of the SLO and as a result of the changes the office made under his leadership, but we cannot say with certainty today who initiated these steps in the first half of 1941.

Government decree no. 93/1941 Sl.z. from 19 May 1941 substantially changed the implementation of land reform. On its basis, Jewish agricultural properties began to be taken into state ownership by regulation of the SLO in the Úradné noviny, which the State Land Office applied for the first time already on 27 May $1941 .{ }^{86} \mathrm{~A}$ working group of the SLO took over the actual implementation of land reform concerning Jewish properties, which represented its main source at this time. Precisely these steps of the new leadership of the SLO meant a substantial turnaround in the speed of land reform. The adoption of the so-called Jewish Code (government decree no. 198/1941 Sl. z.) in September 1941 did nothing to change this. It did not bring many changes to the field of land ownership, with various points only repeating decree no. 93/1941 S1. z. ${ }^{87}$

83 "equally anti-German... but because of his cunning and deceit [Klinovský] is more dangerous than Ševčovič". Tatjana Tönsmeyer adds: "Da sich außerdem die slowakische Regierung nicht zur Durchsetzung einer grundlegenden Bodenreform zugunsten der Kleinbetriebe durchringen konnte, blieb die Umbesetzung letztlich wirkunglos. " TÖNSMEYER, Das Dritte Reich und die Slowakei, p. 220.

84 BArch Berlin, col. R 70 Slowakei, no. 128, Der Berater für Landwirtschaft und Bodenreform, 27 March 1941.

85 SNA, col. 116-25-1/127-136.

86 SNA, col. ŠPÚ, c. 23, Správa o organizácii a celkovej činnosti ŠPÚ, (Report on the organization and general activities of the SLO).

87 Government decree no. 198/1941 Sl. z. ordered the cancellation of tenancy contracts on the basis of which Jews or Jewish organizations rented agricultural property belonging to nonJews, and solved the buying back of properties purchased by Jews at enforced auctions. Slovenský zákonník, 1941, Nariadenie č. 198/1941 Sl. z. o právnom postavení židov (Decree no. 198/1941 Sl. z. on the legal position of Jews). 
By the end of 1941 the State Land Office issued more than 20 regulations in the Úradné noviny transferring Jewish property with an area of 24,809 ha in 237 municipalities into the possession of the Slovak state. This was about a quarter of the estimated total Jewish land in Slovakia. ${ }^{88}$ At the same time, 8,116 ha of Jewish land in 80 municipalities was distributed to form 64 family farms with an average size of 8-11.5 ha. However, a large part of the land was assigned to supplementing hitherto non-independent farms. The SLO also approved almost all the Jewish applications to sell their property submitted up to 31 May 1941, which transferred 3,588 ha into "Christian hands". ${ }^{89}$ Apart from Jewish land, the property of the "politically enriched" was also a resource for land reform, but only an insignificant part. At the same time, the SLO undertook revision of the property of persons not subject to the government decree on the politically enriched because according to K. Klinovský this was often "forced by the general wish of the public". In the case of the "enriched", it is necessary to distinguish between those whose property fell to the state on the basis of decisions by the Commission for the Politically Enriched, and persons whose awards only had to be revised. The SLO took over the properties that fell to the state and divided them or temporarily left them with the original owner as tenant. The first case of the State Land Office acquiring and dividing property was that of Bohumil Laštovka. It was a property of about 70 ha, which the office divided between three farmers from Orava in the form of family farms. In 1941 the SLO also found tenants for domestic properties that had fallen into the state's hands by decisions of the commission. These were properties of Ivan Dérer, Ján Bečko, Max Adler, Ivan Markovič and Juraj Slávik. The State Land Office took over more properties of the "politically enriched" in 1941 but did not always distribute them. The SLO "liquidated" and divided about 1000 ha of land in this category up to December $1941 .{ }^{90}$ The sale of land belonging to foreigners (about 42,064 ha) and nonJewish Slovak citizens (1,761 ha) after obtaining permission from the SLO also continued. ${ }^{91}$

When presenting the results of the activity of his office from the last year in January 1942, Karol Klinovský emphasized that when implementing the land reform, "the higher state interest has first place". The chairman of the SLO also expressed himself in the same spirit later: "When transferring Jewish agricultural property into competent Christian, Slovak hands, it is necessary to care-

88 SNA, col. ŠPÚ, c. 23, Správa o organizácii a celkovej činnosti ŠPÚ.

89 This is the area sold since 1939. SNA, col. ŠPÚ, c. 23, without no.; SNA, col. ÚPV, c. 241, no. 40/1942.

90 SNA, col. ÚPV, c. 241, Správa o činnosti ŠPÚ v roku 1941 (Report on the activity of the SLO in 1941).

91 Ibid. 
fully consider that the state as a careful supporter of its citizens will not suffer losses to production and will not lose reliable tax payers. " ${ }^{2}$ However, the emphasis on maintaining stable agricultural production in the country was not connected only with the need to ensure supplies to the home market. Obligations to supply the German Reich with the main emphasis on fruit, vegetables, meat, milk and fat also made a significant demand on Slovak production. At the end of 1941, German representatives insisted at inter-state negotiations that four fifths of Slovak surplus agricultural production had to be exported to Germany. In connection with this, the state gradually took control of the purchase, distribution, sale, exporting and importing of agricultural products. ${ }^{93}$

Fears of the negative impact of land reform and especially of the division of large properties were not unjustified in Slovakia. In some places they led to difficulties in supplies of basic foods leading to dissatisfaction among the majority population. The debts associated with Jewish properties were also a considerable problem. They represented a considerable value and the creditors of the original Jewish owners, to a considerable extent banks, had justified concerns. Act no. 46/1940 Sl. z. and other legal norms concerning land reform brought some action in this area. At the end of June 1941, the government decided that when liquidating and securing Jewish loans, the SLO should be as helpful "as possible" to the financial institutions and consider their demands when setting the value of properties. ${ }^{94}$ Therefore, the banks opposed the division of large indebted properties because of fears for loans granted to the original owners, and demanded that the SLO respect their claims.

\section{The influence of the deportation of Jews on the land reform process}

The most drastic persecution measures of the Slovak Republic against the Jewish minority - deportation - immediately affected the course of the land reform based on the government and SLO measures of 1941. Starting in March 1942, 58,000 persons were forcibly deported across the frontiers of the state. They included a large number of farmers, which created a serious problem for the SLO. The land office was not able to secure the economic running of abandoned Jewish properties in such a short time, but could not allow them to be neglected.

The adviser Hans Hamscha played an interesting role in solving this situation. At a personal meeting with K. Klinovský on 14 April 1942 he agreed with the chairman of the SLO on the view: "dass die jüdischen Landwirte grösstenteils

92 Ibid., Správa predsedu ŠPÚ o činnosti v roku 1942 (Report on the activity of the SLO in 1942).

93 HALLON - SABOL, ref. 31, p. 416.

94 SNA, col. ŠPÚ, Obežníky ŠPÚ v roku 1941 (Circulars of the SLO from 1941). 
sofort entbehrlich sind " ${ }^{95}$ Hamscha regarded the Jewish landowners and tenants as an element sabotaging the land reform and neglecting the property that concerned him. With regard to care for former Jewish properties that had still not passed into "Aryan" hands, he proposed to Klinovský the establishment of three central inspectorates headed by experienced people, who would supervise the transitional administrators of the Jewish properties. These three inspectors would be subject to a similarly experienced central director, who would work at the SLO. Three days later he also turned to the prime minister with the same idea. Hamsche expressed in a letter to Tuka his conviction "dass eine rasche und radikale Lösung der Judenfrage in der slowakischen Landwirtschaft jetzt und insbesondere auf lange Sicht gesehen, dieser zu einem Segen gereichen wird" ${ }^{96}$ He also gave further detail on the role of the proposed central inspectors, who would be responsible for the western, central and eastern regions of Slovakia. ${ }^{97}$ This development eventually led in June 1942 to passing of the Act on Securing the Running of Agricultural Properties Cultivated by Jews no. 108/1942 Sl.z., which established the Fund for Administration of Agricultural Properties (hereinafter FAAP) at the SLO in June 1942. The fund had the task of administering Jewish land where the implementation of land reform had not begun, and the distributing commission had not distributed or sold the land to applicants. It was not the legal successor to the original Jewish owner, only the administrator of property for the SLO.$^{98}$ Not long before, all Jewish agricultural properties had been taken into state ownership on the basis of decree no. 231 from 13 May 1942 in the Úradné noviny.

Member of parliament František Bošñák was appointed to the function of director of the fund. Local branch offices subject to the control of the regional inspectors began to be established in July and August 1942 immediately after the publication of the fund's statute.

The Fund for Administration of Agricultural Properties administered agricultural properties for fees paid to the State Land Office. The properties had fallen to the state on the basis of decree no. 198/1941 Sl. z. (if it placed them under the SLO) or the Ministry of the Economy placed them according to act no. 108/1942 Sl. z. for use without payment. The properties were either run directly or were let to tenants until their destiny was definitively decided. ${ }^{99}$

95

96

97

98 99

"... that most of the Jewish farmers are immediately dispensable."

"... a quick and radical solution of the Jewish question in Slovak agriculture will be a blessing now and especially from the long term point of view."

SNA, col. ŠPÚ, c. 18, no. 117/42 os.

Slovenský zákonník, 1942, Zákon č. 108/1942 S1. z. o zabezpečení hospodárenia na pol’nohospodárskych nehnutel'nostiach, Židmi obhospodarovaných (Act no. 108/1942 S1. z. on Securing the Running of Agricultural Properties Cultivated by Jews).

Ibid. 
The leadership of the fund sometimes solved the acute shortage of qualified local administrators by leaving the former Jewish owners in the nationalized properties as advisers. The significant number of Jewish employees of the fund, reaching about 400 in 1943, ${ }^{100}$ together with their families gained protection unusual in Slovak conditions, not only from deportation but also from persecution by the domestic regime.

In a very short time, the fund took into its administration extensive properties of former Jewish owners. By the end of 1942, the SLO had handed over more than 14,000 ha of agricultural properties. According to a report by K. Klinovský from 30 September 1943 there were already 16,311 ha of plough soil, 3,739 ha of meadows and pastures, 131 ha of vineyards and fruit orchards, 6,388 ha of forest and 528 ha of other land making a total of 27,097 ha. The Ministry of the Economy administered the forests that had still not been handed over to the FAAP. However, the report did not include the land that the fund let to tenants. There were more than 600 such properties with a total area of 6,213 ha, mostly in smaller economic units of up to 10 ha. ${ }^{101}$

In spite of the fact that the land reform had been under way for a long time, the SLO still did not know exactly how much Jewish land was included in it. The basic pre-condition for Aryanization - registration of Jewish property - was already done by the Slovak government in summer 1939, but the unreliability of the information in this register made it necessary to repeat the registration in the following years. It was not only a matter of cases of property not included in the register of Jewish property whether deliberately or by mistake, but also of the ever widening conception of what the state regarded as Jewish property. Properties not classified as Jewish in 1939, found their way into this group as a result of the ever increasing persecution measures of the Slovak government. Therefore in 1942 the SLO produced a new register, according to which Jews owned 80,766 ha of land in Slovakia, but since this did not include land that had already passed into "Aryan" ownership in the preceding period by award or purchase, the SLO added a further 8,771 ha. ${ }^{102}$ From this amount, the SLO awarded or sold up to 1

100 SNA, col. FSPM (FAAP), Dodatky (Supplements), no. 875/44-S.

101 According to information from the SLO, 250 economic units with areas of $30-300$ ha were run by local administrations in 1943. At this time, the fund managed about 33,000 ha of land, including 1,800 ha of supervised properties. A little later, in March 1944, it administered 25,875 ha of agricultural land, in June 1944 already 28,736 ha. On the basis of an undated report, Jiř́ Doležal states that the fund had 364 units, more than half with more than 20 ha and 77 with more than 100 ha. SNA, col. ŠPÚ, c. 11, no. 102/43-os., SNA; col. FSPM, Počiatočný a konečný inventár dozorných majetkov Fondu (Initial and final inventory of the properties supervised by the fund); RYCHLÍK, Priprava a priebeh pozemkovej reformy, ref. 1, p. 156; DOLEŽAL, ref. 1, p. 345-346.

102 SNA, col. MH, c. 965, Štatistika pozemkovej reformy (Land reform statistics). 
December 1942 10,154 ha of originally Jewish land in 67 municipalities (a total of 17,885 ha of soil from the land reform in 147 municipalities). ${ }^{103}$ Purchase and sale contracts, which could be concluded up to 31 May 1941 and approved by the State Land Office, changed the ownership of 798 ha in $1942 .{ }^{104}$ At least 22,656 ha of land can be said to have passed into "Christian hands" up to December 1942, after calculating the total area of land covered by the land reform and sales with the approval of the SLO up to the end of 1942.

However, according to the provisions of act no. 46/1940 Sl.z., the SLO had to have wider possibilities to acquire land for the land reform apart from Aryanizing Jewish properties. The unrealistic ideas of its creators concerned especially the right of the SLO to purchase a property of more than 50 ha or its part if a non-Jewish, Slovak citizen owner alienated it. The authors of the reform originally placed their greatest hopes in this resource, but it very soon proved to be false. This is confirmed by the statistics, according to which from the beginning of the validity of act no. 46/1940 Sl.z. to the end of 1942 the land office approved 193 sales of a total area of 5,620 ha, but the right to buy was not applied even once. The acquisition of property from judicially enforced sales of the agricultural property of persons owning more than 50 ha of agricultural land was also rather unsuccessful. Up to the end of 1942, the SLO used this legal provision in only six cases with a value of almost 5 million Ks. Another method of acquiring land for the land reform - buying the properties of foreigners regardless of their size - also remained unused. Essentially, the State Land Office only granted its consent to their sale. From summer 1939, when government decree no. 146/1939 Sl.z. was issued, to December 1942 the office approved the sale of land of foreigners in 495 cases involving an area of 30,133 ha. ${ }^{105}$ At the same time, the SLO allowed some foreigners to acquire land in Slovakia amounting to 266 ha on the basis of the principle of reciprocity.

The State Land Office still devoted attention to revision of the land reform of inter-war Czechoslovakia, but without much success. Up to the end of 1942, it considered 55 properties, but only solved 29 of them. From this number, it took over 15 properties amounting to $2,485 \mathrm{ha}$, and divided them either in regular division proceedings ( $940 \mathrm{ha})$ in the form of shortened awards $(1,326 \mathrm{ha})$ or by means of a small sale (218 ha). ${ }^{106}$ Approval of transfer of ownership, mortgaging

103 SNA, col. ÚPV, c. 241, Správa predsedu ŠPÚ o činnosti v roku 1942, (Report of the Chairman of the SLO on activities in 1942).

104 According to K. Klinovský, such cases involved 3,589 ha up to the end of 1941.

105 However, it is noteworthy that according to a report by K. Klinovský, the office approved the sale of land of foreign citizens with an area of 42,064 ha up to the end of 1941 (!). SNA, col. ÚPV, c. 241, Správa o činnosti ŠPÚ v roku 1941 (Report on the activities of the SLO in 1941).

106 According to K. Klinovský, revision of the first land reform in 1942 involved an area of 1,136 ha belonging to 16 former recipients. SNA, col. ÚPV, c. 241, Správa predsedu ŠPÚ o činnosti 
or tenancy of land obtained from confiscation also fell into the activity of the SLO. In the period 1939-1942, the office allowed further transfer of ownership according to $\S 7$ of the so-called Confiscation Act in 176 cases involving a total of 11,534 ha. ${ }^{107}$

As was stated above, the SLO was also responsible for solving cases of " $p o-$ litical enrichment" through a commission established for this purpose. However, practice showed that the regime mainly pursued its own propagandist aims when revising the property of this category of person. At the end of 1942 the office estimated that it had gained about 17,250 ha of agricultural land from these measures, but it had taken over only 15 properties, 9 of them agricultural (735 ha) and 6 of them houses or other buildings. ${ }^{108}$

In connection with the activity of the SLO in 1942, it is also necessary to mention its role in the conclusion of several years of negotiations with Hungary regarding harm to Slovak refugees from the lost territories, culminating in the signing of a mutual agreement in February 1942.

A great problem with evaluating changes in the distribution of land holdings after 1939 and the associated land reform is the contradictory nature of the statistical data, and not only those derived from different sources. Information about the results of reform from the SLO itself is often contradictory. This is seen in statistics from 1943, which do not correspond to the state of the reform at the end of 1942 stated above. According to this source, 4,757 ha of land (574 cases) changed owner by means of approved sales up to December 1942, and the SLO "liquidated" through the land reform 18,991 ha of former Jewish land in 201 cadastral territories in the same period. ${ }^{109}$ In 1941 and 1942, 79 family farms were created from it, as well as 33 larger property units, 3,047 small awards and 48 other types of award - resettlement of people from Orava, tenancies for colonists, commercial distilleries, brickworks and so on, amounting to a total of 3,207 awards. ${ }^{110}$ The people from Orava came from the area flooded by the Ora-

$\mathrm{v}$ roku 1942.

According to the historian J. Rychlík, the state of the distribution of Jewish land in 1942 was as follows: assigned in the framework of the reform 22,441 ha and FAAP 16,311 ha, total 38,752 ha. Although 8,136 ha belonged to the fund, it was held by tenants. SNA, col. FSPM, c. 1, 328/44-S. RYCHLÍK, Príprava a priebeh pozemkovej reformy, ref. 1, p. 156.

107 SNA, col. MH, c. 965, Štatistika pozemkovej reformy.

108 Ibid.

109 According to the statistics there were approved sales of Jewish land in 1939 in 50 cases $(1,238$ ha), in 1940 in 137 cases (1,421 ha), in 1941 in 287 cases (939 ha) and in 1942 in 100 cases (1,159 ha). The SLO distributed or sold in 19415,173 ha of Jewish land in 87 municipalities and in 1942 13,818 ha in 114 municipalities. SNA, col. MH, c. 965, Štatistika pozemkovej reformy. For further details see: RYCHLÍK, Pozemková reforma, ref. 1, p. 259-263.

110 SNA, col. MH, c. 965, Štatistika pozemkovej reformy. 
va Reservoir. The inhabitants of the flooded area had to be compensated using Jewish property.

The further development of the land reform in 1943 was characterized by a clear decline in the Aryanization of Jewish property, which was at that time the only relevant source of agricultural land to be distributed. In this period, distribution of land had to involve only smaller plots or inexpertly managed properties. The division of larger Jewish estates decreased as a result of the national economic consequences. ${ }^{111}$

In the framework of changes to implementation of the reform in 1943, the SLO cancelled by means of decree no. 341/1943 Úradné noviny arendal and tenancy agreements concerning former Jewish agricultural properties (arendas were cancelled in a total of 613 municipalities ${ }^{112}$ ) and established a method for awarding and selling Jewish properties in simplified award proceedings or public auctions in which only members of HSPP and frontline soldiers could participate. ${ }^{113}$ According to the historian Jiří Doležal, 2,700 public auctions were held in 1943 and in the following year already only 560 . The average price was 13,500 Ks for 1 ha. 2,204 ha were auctioned, 1,722 of them in $1943 .{ }^{114}$ The office awarded 3,396 ha of land in 1943 in the framework of regular award proceedings. ${ }^{115}$ According to K. Klinovskýs reports, the State Land Office had to award or sell 22,515 ha of Jewish land by the end of September 1943. ${ }^{116}$

In 1943 we still find transfer of Jewish land on the basis of approval of purchase contracts by the State Land Office, although there were only 41 of these sales involving an area of 507 ha. Jiří Doležal calculated the average price of this land as about $14,500 \mathrm{Ks} .{ }^{117}$ According to data about the activity of the State Land Office up to 30 September 1943 provided to parliament, 4,757 ha of land passed into "Christian hands" in this way. Christians obtained a total of 27,272 ha of Jewish land up to that date, if we add the land that passed through the land reform. ${ }^{118}$

111 DOLEŽAL, ref. 1, p. 345

112 According to J. Doležal a total area of 2,355 ha was involved.

113 The handing over of properties to new owners was reformed in the interest of speeding up the land reform by a July 1944 circular of the SLO on award proceedings on the basis of the highest offer from applicants. SNA, col. Pracovná skupina (Working Group, hereinafter PS) E pri ŠPÚ (E at the SLO), c. 159, Obežník (Circular) no. 3516/43 prez.

114 RYCHLÍK, Príprava a priebeh pozemkovej reformy, ref. 1, p. 157; DOLEŽAL, ref. 1, p. 347.

115 DOLEŽAL, ref. 1, p. 347.

116 SNA, col. ŠPÚ, c. 19, no. $4159 / 43$ prez.

117 DOLEŽAL, ref. 1, p. 336.

118 However, doubts are raised by the fact that other data from the SLO mention an area of 4,757 ha from approved sales up to the end of 1942. 


\section{The final phase of land reform in Slovakia}

According to J. Doležal only 560 public auctions involving 482 ha were held in $1944,{ }^{119}$ while regular award proceedings by the office awarded only 493 ha of Jewish land. ${ }^{120}$ However, these may not be exact data because only from September to the end of December 1944, Gardista published information about auctions and awards of Jewish property amounting to 1,641 ha, which were gained by 1,380 persons including 415 soldiers. The content of the documents from Working Group E at the SLO and the local reports of the FAAP for the territory of its districts (Hlohovec and Nitra), according to which more than 400 ha of Jewish properties were taken from the fund and sold in 1944, followed by more than 200 ha sold in 1945 (!), do not entirely correspond to J. Doležal's figures. Sale and also fragmentation of large properties occurred at least in 1944 also outside the land directly administered by the fund.

We can connect the deviation in 1944 from the principle of not dividing large properties with the worsening financial situation of the state in this period. This is shown by the record of a session of the Slovak government on 8 August 1944, which decided to solve the state's financial difficulties in the field of paying obligations and covering its needs by taking loans from the Slovak National Bank amounting to 300 mil. Ks payable by 30 September 1944. By that date, the Ministry of Finance had to propose and prepare measures needed to improve the position of the state treasury. According to the government, they considered various resources, not forgetting the property taken from the decimated Jewish community. The specific proposals included the use of money from Jewish deposit accounts and their frozen accounts, as well as the profits from the sale of former Jewish properties administered by the Central Economic Office and SLO. Finance drawn by local government, extension of obligatory holding of state securities, namely forced loans, and widened use of supplier's vouchers had to bring further money. Transfer of some, especially social tasks to other public institutions also had to reduce the load on the state. ${ }^{121}$ In the light of this information, it appears to be no accident that at its meeting a few days later on 17 August 1944, when it was already difficult to doubt the result of the war, the government heard a report from K. Klinovský on the state of the land reform and took into account his "promise" that 2,301 ha from the property of the FAAP ${ }^{122}$ would be

119 RYCHLÍK, Príprava a priebeh pozemkovej reformy, ref. 1, p. 157; DOLEŽAL, ref. 1, p. 347.

120 DOLEŽAL, ref. 1, p. 347. Vlastislav Bauch states that according to a report on the land reform from 17 Aug 1944 this was done for 32,471 ha of land. BAUCH, Pozemková reforma, ref. 1, p. 378.

121 SNA, col. Národný súd (National Court, hereinafter NS), Tn 74/75 Gejza Fritz, mf. A-881, Zápisnica zo zasadnutia vlády (Minutes of a government meeting) from 8 Aug 1944.

122 Interesting data shedding light on the overall activity of the FAAP was produced by the Com- 
awarded or sold. ${ }^{123}$ The Ministry of Finance and the Ministry of Transport and Public Works also promised to help the SLO by providing surveyors. ${ }^{124}$ Thus, up to the last moments of the regime, the government enabled persons loyal to HSPP to enrich themselves from Jewish property. Obviously, it was not a new phenomenon, implementation of the land reform was closely connected from the beginning with the organizations of HSPP, ${ }^{125}$ the Hlinka Guard, representatives of municipalities and the highest state representatives, without whose approval and assessments, an applicant for an award could hardly expect success. However, the selection of recipients of land began to be directed entirely by political criteria, especially in connection with the changed military situation in 1943, when the state allowed only party members and frontline soldiers to participate in auctions of land.

Regardless of the fact that exact evaluation of the results of the land reform is prevented by the incomplete and often contradictory data about its course, it is clear that the expectations placed in it by the Slovak public and political representatives were not fulfilled. The ideas of the Minister of the Economy Medrický from 1939 about the creation of a strong agricultural middle class, which would

mission for Agriculture and Land Reform in April 1948 when it carried out the liquidation of the fund. According to this data, the fund lacked 510 million Kčs at this time. From this advances from the SLO formed 35 million Kčs, while tax debts were of similar size and unpaid bills for the use of property up to the passing of the front amounted to 14 mil. Kčs. However, the largest item was the debts deriving from restitution claims by the original owners amounting to 350 mil. Kčs. This sum represented the equivalent of the revenue from the properties administered by the fund during the period when the original owners could gain no benefit. However, it is not clear today how the commission produced these figures. In the same period, the fund still owed the SLO a sum of 28 mil. Kčs, and still recorded receivables of 25 mil. Kčs for wartime deliveries. According to this source, the fund evaluated war damage to its property as 66 mil. Kčs, but documents show that soon after the war, the FAAP estimated a similar item at more than 91 mil. Kčs. SNA, col. FSPM, c. 8, without no.; NA Praha, col. MV I-NR, c. 2484, no. B 2640/1.

123 SNA, col. NS, Tn 20/45, mf. A-864, Čiastočný výpis zo zápisnice zasadnutia vlády (Partial copy of the minutes of a session of the government) from 17 Aug 1944.

124 The head of the accounts office of the SLO Pavol Drahoš stated in his testimony to the National Court, that in July 1944 the SLO was asked by the ministers of the Economic Committee to "release a sum of 150,000,000 crowns for the Finance Ministry under the title of measues of mobile financial resources... but the accused [K. Klinovský] defended himself, insisting that it should only be a loan for one year and the sum should be reduced to 50,000,000 crowns. The SLO got this sum back by the end of 1945. The Ministry of Finance used only 2-3 million crowns from this sum." SNA, col. NS, Tn 20/45, mf. A-863, Výpoved' Pavla Drahoša zo 17. 1. 1946 pred Národným súdom, (Testimony of Pavol Drahoš to the National Court on 17 Jan 1946).

125 In the archive materials we find a multitude of repeated interventions, especially from the General Secretariat of HSPP. 
gain a firm economic base from the reform, so that it would reliably stand "as a healthy, persistent and well-endowed backbone of the Slovak nation" ${ }^{26}$ remained only an illusion.

The reason is not only the fact that the land reform in the Slovak state was never completed. As a result of its method and concrete implementation, it could never have a really significant social and economic impact on the Slovak village. Therefore, the ruling regime was not able to achieve its aim of "Slovakizing" land ownership, building up a strong farming class in the country and creating "a healthy type of Slovak person" or "independent and self-confident individual, ${ }^{127}$ who would be its support.

* The study was produced in the framework of the projects: VEGA no. 2/0071/15 Slovakia in inter-war Czechoslovakia and the wartime Slovak Republic - questions of discontinuity and continuity in politics, the economy, society and culture. The Individual and Society - their Mutual Reflexion in Historical process. This work is the partial result of the Project Individual and Society - their Mutual Reflexion in Historical Process granted by Slovak Research and Development Agency under the contract No. APVV-15-0349.

\title{
Vorbereitung und Verlauf der Bodenreform in der Slowakei, 1939-1945
}

\author{
MARTINA F I A MOV Á
}

Das Hauptziel der slowakischen Bodenreform aus den Jahren 1939-1945, das von der Regierungsmacht auch der Öffentlichkeit präsentiert wurde, beruhte in der Bildung einer starken mittleren Bauernschicht als „Elite und Wirbelsäule“ des slowakischen Volkes. Dieses Ziel stand im Zusammenhang mit der proklamierten Absicht der slowakischen Regierung, die sozialen Probleme der Landwirte zu lösen, wozu sich die Regierung schon während der Vorbereitung des Gesetzes über die Bodenreform äußerte. Auf der anderen Seite war die Befriedigung der Bodenansprüche der Mehrheit der slowakischen Bauern nicht realistisch. Die Art, wie das Gesetz über die Bodenreform vom 1940 geschrieben wurde, stellte ihre Verwirklichung in so komplizierter Weise dar, dass sich der erste Ankauf und die Zuteilung des Bodens erst im April 1941 vollzogen.

In der gleichen Zeit wurde zugleich offensichtlich, dass die einzige tatsächliche Quelle der Bodenreform nur der Boden von Juden sein kann. Der Vorgang der Bodenreform in der Slowakei reduzierte sich allmählich auf die Arisierung. Der Boden sollte den „moralisch

126 Slovák-Týždenník, 1939, year 20, no. 42, p. 4.

127 Slovák, 1940, year 22, no. 47, p. 1. 
erhaltenen" slowakischen Bürgern - Christen - zugeteilt werden. Trotz der wiederholten Erklärung des Staatlichen Bodenamtes, das mehrfach die Absicht erklärte, die Reform im Interesse „des gesamten Volkes“ und nicht nur manchen Einzelpersonen zu verwirklichen, war die Wirklichkeit eine andere. Im Rahmen der Reform wurden oft die Interessen der Personen berücksichtigt, die mit Hlinkas slowakischen Volkspartei verbundenen waren, die der Regierung loyal waren und die, die in der Ausstoßung der Judengemeinde aus dem wirtschaftlichen Leben eine große Gelegenheit zu Selbstbereicherung sahen. Durch solche Einbeziehung der Mehrheitsgesellschaft in die Verbrechen, gerichtet gegen Juden, versuchte das Regime auch ihre Treue zu „kaufen“. Die Ergebnisse der Reform erfüllten aber die Erwartungen der Regierung nicht und ihre Bodenreform brachte keine prinzipiellen Änderungen auf dem slowakischen Lande.

PhDr. Martina Fiamová, PhD.

Historický ústav SAV

P. O. BOX 198, 81499 Bratislava, Klemensova 19

e-mail: histfiam@savba.sk 